\title{
ASPECTS OF BARLEY PHYSIOLOGY TREATED WITH ALS HERBICIDES
}

\author{
Nicolaie Ionescu ${ }^{1, *}$ \\ ${ }^{1}$ Agricultural Research and Development Station Piteşti, Piteşti-Slatina road \# 5, 117030, Piteşti, România
}

\begin{abstract}
Preservation of environment is a necessity, as well as ensuring the sustainability characteristics of agricultural production (Abeledo et al., 2002). Such measures require the use of herbicides as closely as possible. In this paper we refer to some herbicides belonging to ALS group. Lately, they have been used incorrectly, not recommended, in winter barley crop. Excessive infestation with new, invasive, monocotyledonous species from genus: Avena, Apera, Bromus, Lolium, Vulpia, was found in the practice. Against this, there are currently no sustainable control solutions in this crop. Although it was known that some products from this group of herbicides are not recommended for the treatment of barley, farmers have tried them, even at the risk of predicted adverse effects. The negative effects were obvious. Winter barley does not have the enzymatic equipment necessary to metabolize it, and the plants suffer. To highlight such phytotoxic phenomena, some investigations have been carried out. Thus, compared to untreated ALS barley, the plants showed a smaller size of 20-25 cm, the weight of the ears was less with $1.1 \mathrm{~g}$, they formed with 15 grains less in an ear, the sterility increased by 50\%, and TGW-thousand grain weight was reduced by 10 grams. Lack of barley selectivity for such treatments can cause significant production losses, both total and grain. It is currently working to find active ingredients with total selectivity for winter barley.
\end{abstract}

Keywords: ALS inhibitors, ears, empty grains, full kernels, straw length, winter barley.

\section{INTRODUCTION}

Like other autumn cereals, barley is grown every year with various species of dicots (usually those adapted here) and monocots species (recently). In order to minimize the degree of infestation with the whole spectrum of weeds, we use the most effective and most comprehensive herbicides of the complex type. The new problem is the high density of monocotyledonous of Avena, Apera, Bromus, Lolium, Vulpia. Against this, there are limited possibilities to fight. It is known that products from the ALS group are not recommended for their control in barley crop. The mode of action of these herbicides is at the ALS- acetic lactate synthase (or AHAS- acetic hydroxy acid synthase) enzyme. After application of these herbicides to the crop and weeds, the ALS (AHAS) enzyme is blocked, after which the mono-amino- mono-carbon acids biosynthesis of valine (Val), leucine (Leu) and isoleucine (Ile) stops. The immediate consequence is the rapid cessation of the growth of all treated plants, since stopping the synthesis of these proteins negatively affects DNA synthesis and cell growth, followed by cell division and ceasing of plant growth. Barley weeds will perish (died) in about 2 weeks while barley plant will remain small, will form ears and grains with specific damaged characters. From the metabolic and physiological point of view (Mishra \& Shivakumar, 
2000), herbicides recommended for barley crop do not produce any phytotoxic phenomenon due to the presence of an important group of substances that convert herbicidal molecules into non-toxic metabolites. The substances are enzymatic and belong to the glutathione-S-transferase group (GST) (Edwards 1997). Their role consist in electriphilic detoxification of herbicides that reach barley plants. The mode of action of GST consists of catalyzing the conjugation of herbicides molecules with glutathione (gamma-glutamyl-cysteinyl-glycine). Glutathione is a major cellular thiol, which together with glutathione- dependent enzymes perform roles in detoxification buffering as well as redox reactions (Zglimbea \& Harms, 1997). Herbicidal detoxification in barley plants occurs with conjugation of glutathione through reactions. Within them there is a replacement of the sequence that induce toxic reactions with another nontoxic reaction, after which the herbicide is transformed and eliminated. The group of classes belonging to GST are: phi-F, theta-T, tau- $\mathrm{U}$, and zeta-Z. One of these is characteristic to barley plants. After the detoxification of a herbicide there is an export of residues remaining outside the cell metabolism. First, the residues will enter into the cell vacuole (Coleman et al, 1997). The glutathione-type conjugates enter into processing reactions initiated by the hydrolysis of the glycine residue, namely a specific vacuolar carboxypeptidase. The dipeptide conjugate can be re-exported from the vacuole into the cytoplasm (cyto-solution) and is associated with the glutamate mutation by gamma-glutamyl transpeptidase. S-cystenyl derivates may follow a variety of subsequent transformations, including $\mathrm{N}$-malonylation and subsequent degradation to a wide range of polar metabolites, some of which are herbicide residues and can be incorporated into natural products such as mature grains (Tal et al., 1993). Many herbicides follow this pathway of glutathione in the course of their metabolism and detoxification in crop plants. By appropriate research, it can be demonstrated that the ALS- type herbicides applied to barley cause changes and even physiological disorders (Brad et al., 1972; Cuesta-Marcos et al., 2009), resulting in a plant alteration in general and in the reproductive part. This research has demonstrated some deviation from the normal physiology of herbicide-treated barley plants of ALS type by several determinations of mature plants.

\section{MATERIALS AND METHODS}

From ALS group, Floramix TM herbicide (containing piroxulam $70.8 \mathrm{~g} . \mathrm{kg}^{-1}+$ florasulam $14.2 \mathrm{~g} \cdot \mathrm{kg}^{-}$ ${ }^{1}+$ cloquintocet-methyl safener) with the Dassoil 26-2N 0.6 litre/ha adjuvant in the winter barley crop, was applied to the Sistem variety, twinning phase- formation of the first internode, currently recommended in normal treatment. The dose used was $250 \mathrm{~g} / \mathrm{ha}$ PC (maximum dose) due to the very high degree of monocot weeds infestation. The appearance of ALS treated barley plants was totally different from normal (Figure 1 and Figure 2). The variant treated with this herbicide was part of an experience with different barley agro-technical treatments (Cattivelli et al., 2011). The experience was set up by the block method, with variants of $25 \mathrm{~m}^{2}$ in 4 replicates. The technology used was the one recommended by the resort. At the full maturity, 25 plants/stems from each repetition (total 100) were randomly picked and brought to the laboratory. The 100 strains were measured and determined: the total length of the straw, the length and weight of the ears, the number of grains (spikelets) and their weight, and thousand grains weight (TGW). Between the analyzed characters the correlations were established, with the help of which their tendencies in the barley plants affected by the herbicide could be observed. The Excel program was used to express the values. 


\begin{tabular}{lcr}
\hline & $\begin{array}{c}\text { Current Trends in Natural Sciences } \\
\text { Vol. 9, Issue 18, pp. 64-74, 2020 } \\
\end{array}$ & $\begin{array}{c}\text { Current Trends in Natural Sciences (CD-Rom) } \\
\text { https://doi.org/10.47068/ctns.2020.v9i18.010 }\end{array}$ \\
\cline { 2 - 3 } Current Trends in Natural Sciences (on-line) & ISSN-9521 \\
ISSN: 2284-953X & & ISSN-L: 2284-9521 \\
ISSN-L: 2284-9521 & \\
\hline
\end{tabular}

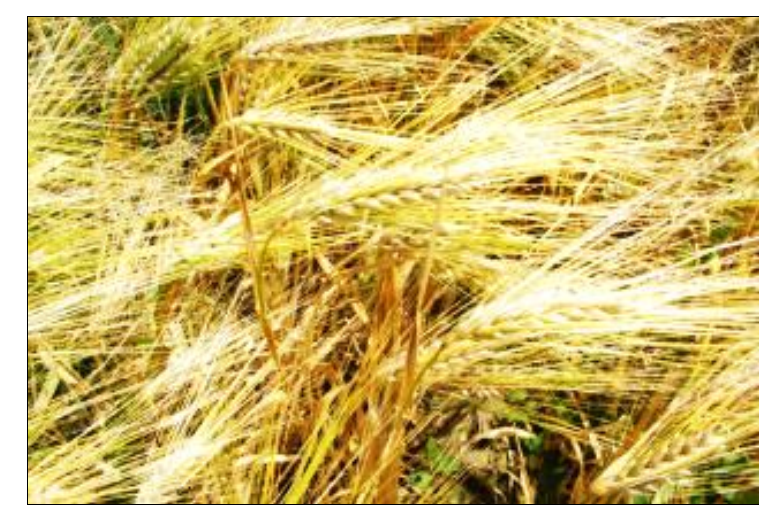

Figure 1. The winter barley plants, no ALS herbicides

The significance of the correlation coefficients was obtained by comparing with $r_{\max }$ values (Erna Weber, 1961) for the 5\%, $1 \%$ and $0.1 \%$ levels of transgression probabilities. In the statistical calculation of the values obtained we used variance analysis (Anova test) on the variation rows. Statistical parameters were calculated using the formula: $\bar{a}=\Sigma x / n$, where $\bar{a}=$ media of determinations, and $\mathrm{x}=$ the values, $\mathrm{S}^{2}($ variance $)=1 / \mathrm{n}-1\left[\sum \mathrm{x}^{2}-\left(\sum \mathrm{x}\right)^{2} / \mathrm{n}\right], \mathrm{S}($ standard error $)=\sqrt{\mathrm{S}^{2}}$, and $\mathrm{S} \%$ (variation coefficient $)=\mathrm{S} / \overline{\mathrm{a}} .100$.

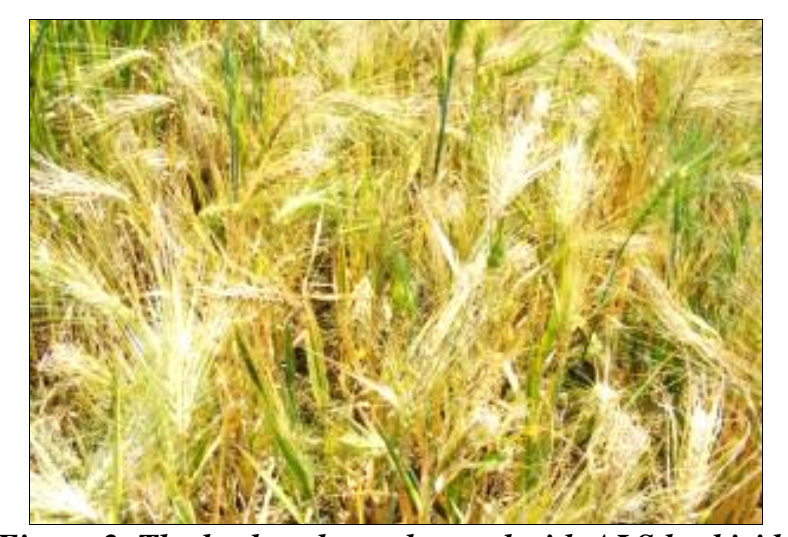

Figure 2. The barley plants threated with ALS herbicide

\section{RESULTS AND DISCUSSIONS}

Ears of barley. The appearance and dimensions of the barley ear are characteristic (Von Bothmer et al. 1995). Thus, its length generally has values ranging from 5 to $10 \mathrm{~cm}$. The weight of mean ear typically ranges between 1.0 and 4.0 grams, depending on the crop conditions. From the barley determinations with the normal physiology of plants, it appeared that the length of the ear was between 4.0 and $8.4 \mathrm{~cm}$. Under ALS herbicide treatment, ear has lengths of 3.3 and $7.3 \mathrm{~cm}$ (Figure 3 and Figure 4). The correlation between the two characters: the length and the weight of the ears shows a high coefficient $(\mathrm{r}=0.8424)$ at the normal ear, while the herbicide-treated ear was a lower level $(r=0.6137)$. The weight of the ear in the untreated barley with this herbicide was between 1.02 and $3.59 \mathrm{~g}$. In the barley with the affected physiology the ears weighted between 0.41 and 2.29 g. 


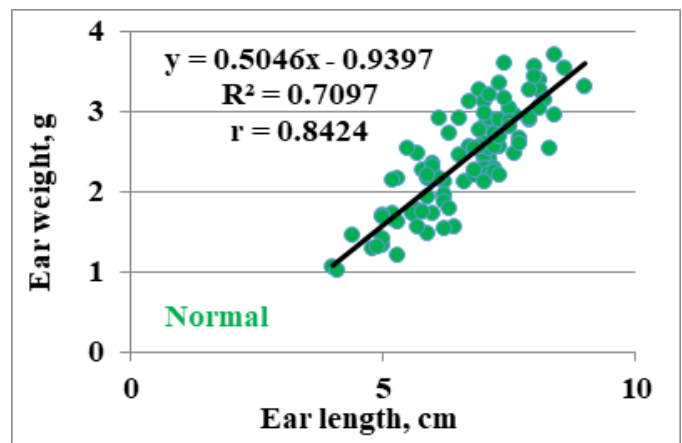

Figure 3. Correlation between ear length and ear weight, normal barley

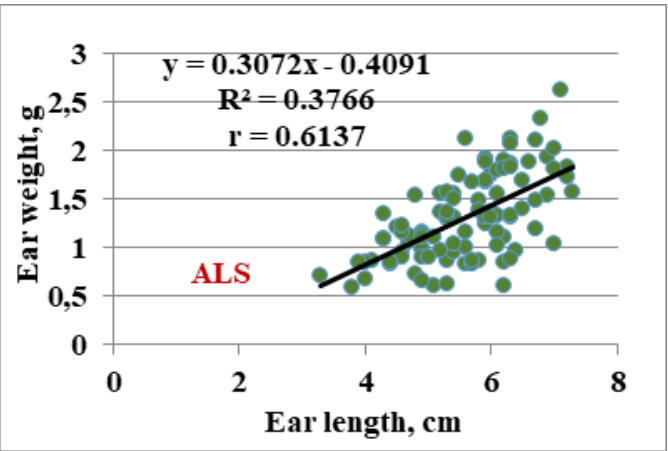

Figure 4. Correlation between ear length and ear weight of affected barley

The statistical indices obtained for the two characters of the barley show that in the case of the ALS treatment the ear length was smaller by about $1 \mathrm{~cm}$. The ear length variability was medium for both situations. The ear weight was reduced to $0.7-1.13 \mathrm{~g}$ treated ear. The variability of the ear weight was high at the normal and particularly high ear in the spleen resulting from the ALS treatment (Table 1). Ears affected by the herbicide, in addition to their reduced lengths, showed the wrinkled appearance (Figure 5).

Table 1. Indices of barley ear length and weight, no ALS and with ALS treatment

\begin{tabular}{|c|c|c|c|c|}
\hline \multirow[b]{2}{*}{ Indices } & \multicolumn{2}{|c|}{ Ear length, cm } & \multicolumn{2}{|c|}{ Ear weight, $g$} \\
\hline & No ALS & With ALS & No ALS & With ALS \\
\hline Variation limits & $4.0-8.4$ & $3.3-7.3$ & 1.02-3.59 & $0.41-2.29$ \\
\hline$\overline{\mathbf{a}}^{*}$ & 6.67 & 5.60 & 2.43 & 1.31 \\
\hline $\mathbf{S}^{2}$ & 1.14 & 0.77 & 0.41 & 19.3 \\
\hline $\mathbf{S}$ & 1.067 & 0.876 & 0.639 & 4.393 \\
\hline $\mathrm{VC}, \%$ & 16.0 & 15.7 & 26.3 & 335.3 \\
\hline & $\begin{array}{c}\text { edia, S } \\
\text { VC }\end{array}$ & $\begin{array}{l}\text { ce, } S \text {-stand } \\
\text { ion coeffic }\end{array}$ & & \\
\hline
\end{tabular}




\section{Current Trends in Natural Sciences}

Vol. 9, Issue 18, pp. 64-74, 2020

https://doi.org/10.47068/ctns.2020.v9i18.010

Current Trends in Natural Sciences (on-line)

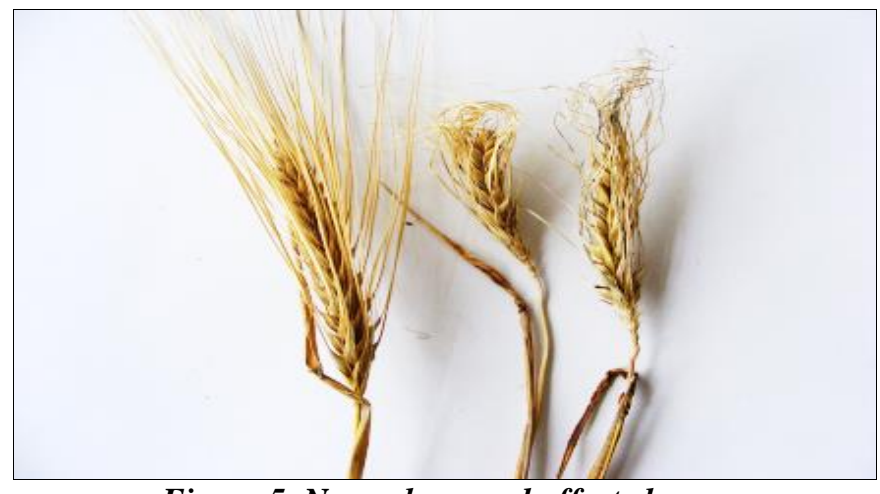

Figure 5. Normal ear and affected ones

Normal (full) barley grains. The grains or barley kernels that are formed have particular characteristics: they are dressed in the lower palea and the upper palea (lemma), having dimensions between 8-12 mm length, 2.0-4.5 mm thickness, elongated shape (Fox et al., 2006). Their number is generally variable and ranges from 15 to $70 /$ ear and their weight is between 1.0 and 3.5 g/ear. From the determinations it appeared that between he two physiological characteristics, there were some differences (Figure 6 and Figure 7). The correlation between the number of grains in ear and their weight was very close to barley with normal physiology $(r=0.9659)$, in a register ranging from 1 to $3 \mathrm{~g}$. In barley treated with ALS herbicide the correlation was as tight $(r=0.9564)$ but in a much lower register, ie between 0.4 and $2 \mathrm{~g}$.

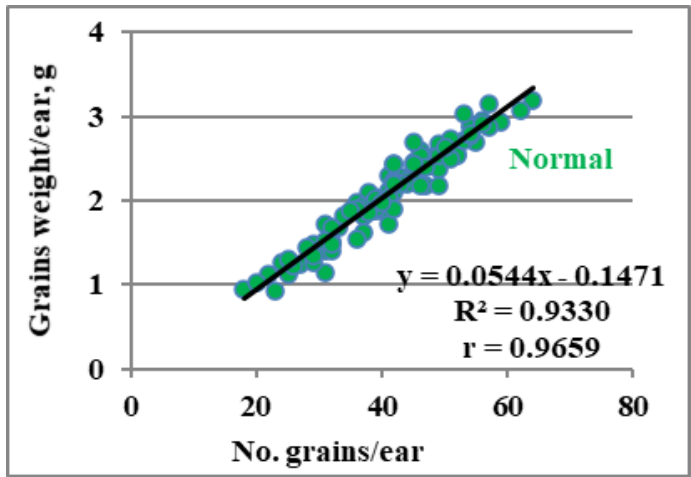

Figure 6. Correlation between grain no./ear and its weight in normal barley

The barley with normal physiology produced between 18 and 64 grains/ear and the barley with affected physiology produced between 7 and 49 grains/ear. The weight of the grains in one ear oscillated between 0.92 and $3.19 \mathrm{~g}$ in normal barley and between 0.41 and $2.29 \mathrm{~g}$ in herbicide attacked barley (Table 2). The variability of two characters of barley ears was high (Jeźowski et al., 2001). The decrease in the number of ear grains in ALS herbicide treatment occurred especially at the peak (Figure 8). 
Current Trends in Natural Sciences

Vol. 9, Issue 18, pp. 64-74, 2020

https://doi.org/10.47068/ctns.2020.v9i18.010

Current Trends in Natural Sciences (on-line)

ISSN: 2284-953X

ISSN-L: 2284-9521
Current Trends in Natural Sciences (CD-Rom)

ISSN: 2284-9521

ISSN-L: 2284-9521

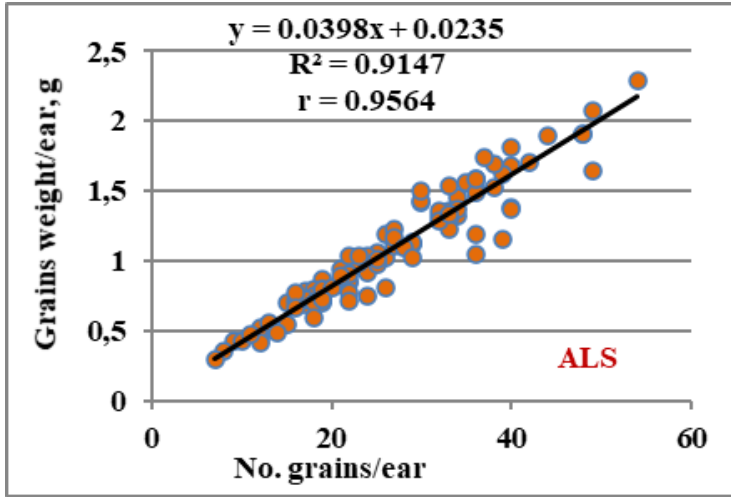

Figure 7. Correlation between grain no./ear and its weight in affected barley

Table 2. Indices of barley grains number and weight/ear

\begin{tabular}{|c|c|c|c|c|}
\hline \multirow{2}{*}{ Indices } & \multicolumn{2}{|c|}{ Nr. grains/ear } & \multicolumn{2}{c|}{ Grains weight /ear, g } \\
\cline { 2 - 5 } & No ALS & With ALS & No ALS & With ALS \\
\hline Variation limits & $\mathbf{1 8 - 6 4}$ & $7-49$ & $\mathbf{0 . 9 2 - 3 . 1 9}$ & $\mathbf{0 . 4 1 - 2 . 2 9}$ \\
\hline$\overline{\mathbf{a}}$ & $\mathbf{4 1 . 1}$ & 26.7 & $\mathbf{2 . 0 9}$ & $\mathbf{0 . 9 8}$ \\
\hline $\mathbf{S}^{\mathbf{2}}$ & $\mathbf{9 8 . 4 4}$ & $\mathbf{1 0 4 . 1 5}$ & $\mathbf{0 . 3 1}$ & $\mathbf{0 . 4 1}$ \\
\hline S & $\mathbf{9 . 9 2 2}$ & $\mathbf{1 0 . 2 0 5}$ & $\mathbf{0 . 5 5 6}$ & $\mathbf{0 . 6 3 9}$ \\
\hline VC,\% & $\mathbf{2 4 . 1}$ & $\mathbf{3 8 . 2}$ & $\mathbf{2 6 . 6}$ & $\mathbf{6 5 . 5}$ \\
\hline \multicolumn{4}{|c}{} \\
\hline & à-media, S ${ }^{2}$-varianța, S-standard error, \\
VC \%-variation coefficient \\
\hline
\end{tabular}

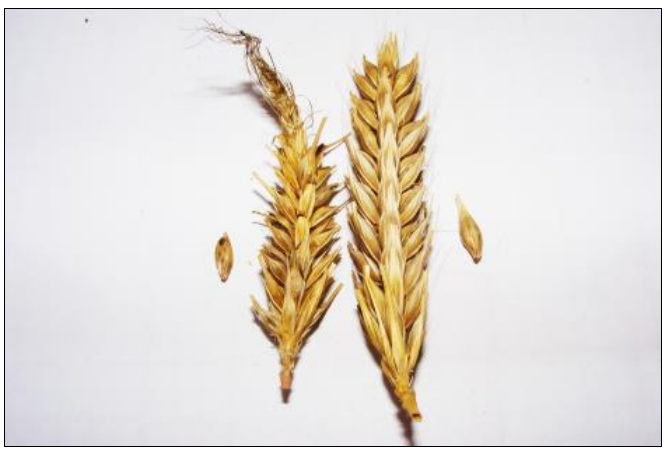

Figure 8. Barley ear affected (left) and the normal one

Sterile barley grains. An obvious category of ALS-treated barley was the number of sterile spikelets (grains). These were observed both at the base, along the length of the ear and especially at the top of the ear. From previous research it has been found that between some characters of the barley plant and these sterile hindquarters there are generally negative connections. Thus, between the length of the straw (Kjaer et al., 1995) and the number of sterile grains in the untreated barley, the correlation had a slight positive tinge (figure 9), precisely because the sterility was quite low. In the case of ALS treated barley, the correlation obtained was negative (Figure 10). The graphs also show that the experimental herbicide also reduced plant size by a shorter straw (Table 3). Together with sterile spikelets (grains), barley grains with physiology affected also had a different appearance than normal (Figure 11). 


\section{Current Trends in Natural Sciences}

Vol. 9, Issue 18, pp. 64-74, 2020

https://doi.org/10.47068/ctns.2020.v9i18.010

Current Trends in Natural Sciences (on-line)

ISSN: 2284-953X

Current Trends in Natural Sciences (CD-Rom)

ISSN: 2284-9521

ISSN-L: 2284-9521

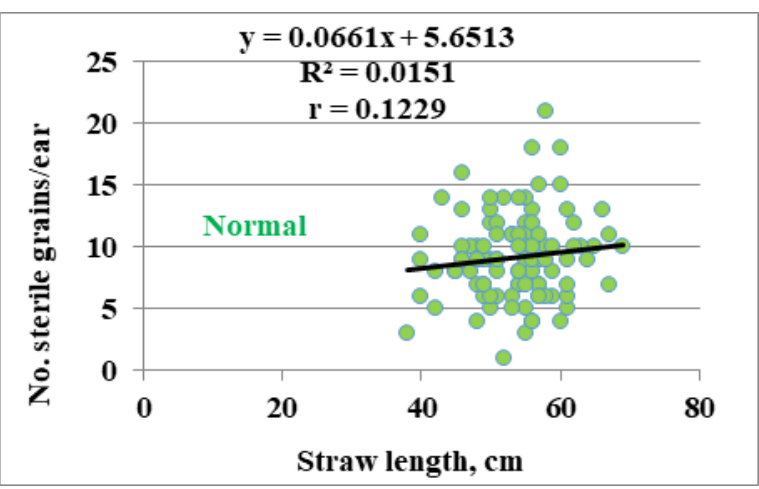

Figure 9. Correlation between straw legth and no. of sterile grains/ear in normal barley

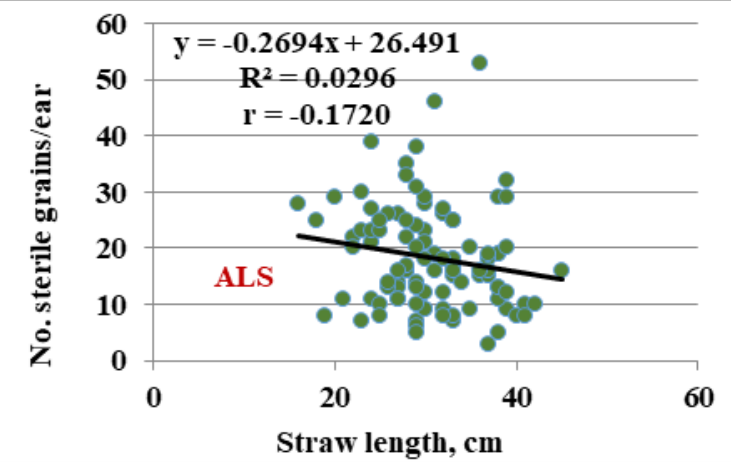

Figure 10. Corelations between straw length and și no. of sterile grains/ear in affected barley

Table 3. Indices of barley straw length and no. of sterile grains/ear

\begin{tabular}{|c|c|c|c|c|}
\hline \multirow{2}{*}{ Indices } & \multicolumn{2}{|c|}{ Straw length, cm } & No. of sterile grains/ear \\
\cline { 2 - 5 } & No ALS & With ALS & No ALS & With ALS \\
\hline Variation limits & $\mathbf{3 8 - 6 9}$ & $\mathbf{1 6}-\mathbf{4 5}$ & $\mathbf{0}-\mathbf{2 1}$ & $\mathbf{3 - 5 3}$ \\
\hline$\overline{\mathbf{a}}$ & $\mathbf{5 3 . 5}$ & $\mathbf{3 0 . 7}$ & $\mathbf{9 . 3}$ & $\mathbf{1 8 . 2}$ \\
\hline $\mathbf{S}^{\mathbf{2}}$ & $\mathbf{4 0 . 9 2}$ & 34.17 & $\mathbf{1 2 . 2 1}$ & $\mathbf{8 9 . 6 9}$ \\
\hline S & $\mathbf{6 . 3 9 7}$ & $\mathbf{5 . 8 4 6}$ & $\mathbf{3 . 4 9 4}$ & $\mathbf{9 . 4 7 0}$ \\
\hline VC,\% & $\mathbf{1 1 . 9}$ & $\mathbf{1 9 . 0}$ & $\mathbf{3 7 . 6}$ & $\mathbf{5 2 . 0}$ \\
\hline \multicolumn{4}{|c}{} \\
\hline
\end{tabular}

Figure 11. Spikelets (grains) of the affected barley (left) and the normal one 
In the case of correlations between the weight of the ear and the number of sterile grains in the two types of plants, similar and at the same time negative situațions were found (Figure 11 and Figure 12). In normal barley, the higher weight of the ear, the number of sterile grains was lower $(r=-$ 0.0141). The situation in this case is however relatively uncertain, with negative tendencies. In barley affected by the ALS herbicide, the correlation between the weight of the ear and the number of sterile grains is clearly negative $(r=-0.3432)$. In "lighter" ears, due to the herbicide-induced phytotoxic effect, the number of sterile grains was very high. In the case of ears with herbicide treatment and heavier in weight, the sterile grains were less, and are explained by the fact that they showed a certain degree of resistance to the herbicidal effect. The relationship between the number of whole grains and the number of sterile grains in barley ears has embraced specific aspects (Figure 13 and Figure 14). The graph shows that sterile spikelets at normal physiological barley were at an average level of 10, compared to which normal spikelets developed into a fairly large register. The correlation has a negative nuance $(\mathrm{r}=-0.0700)$, with very poor statistical assurance. It is possible that barley cultivated under the ecological conditions of the resort produces ears with a variable number of grains, depending on the culture conditions, but with sterile spikelets (grains) around the average of 10/ear. In affected barley, both the number of normal grains and the number of sterile grains had present, demonstrating the phytotoxic effect of the ALS herbicide on barley fruit.

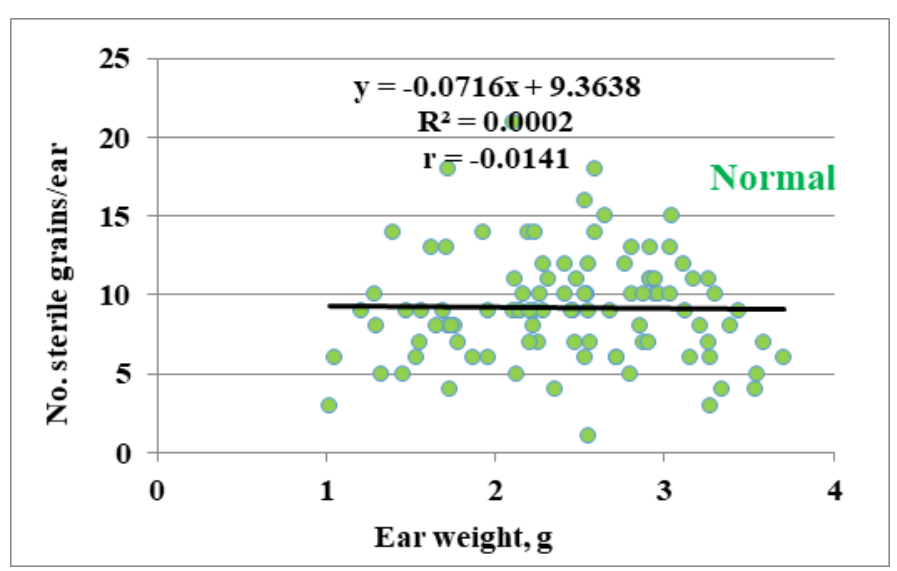

Figure 11. Correlation between ear weight and no. of sterile grains/ear in normal barley

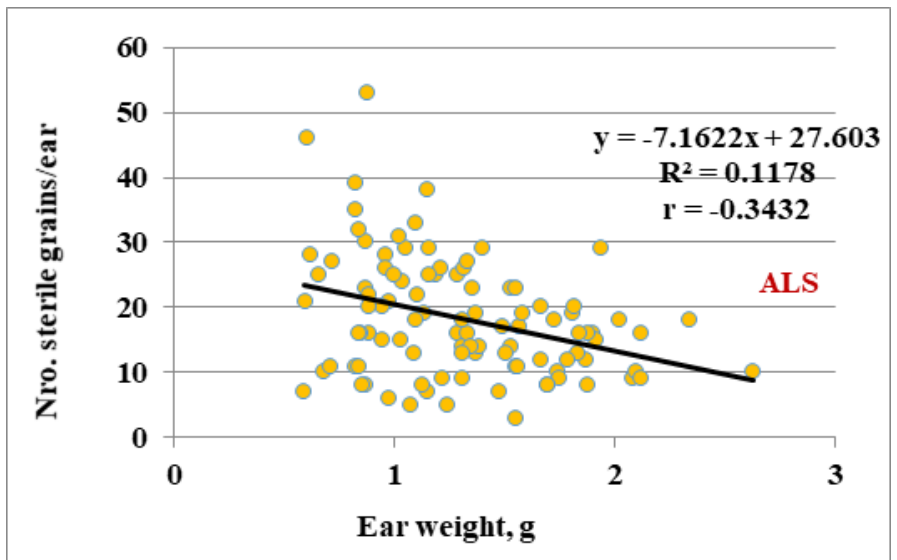

Figure 12. Correlations between ear weight and no. of sterile grains/ear in affected barley 
Current Trends in Natural Sciences

Vol. 9, Issue 18, pp. 64-74, 2020

https://doi.org/10.47068/ctns.2020.v9i18.010

Current Trends in Natural Sciences (on-line)

ISSN: 2284-953X

ISSN-L: 2284-9521
Current Trends in Natural Sciences (CD-Rom)

ISSN: 2284-9521

ISSN-L: 2284-9521

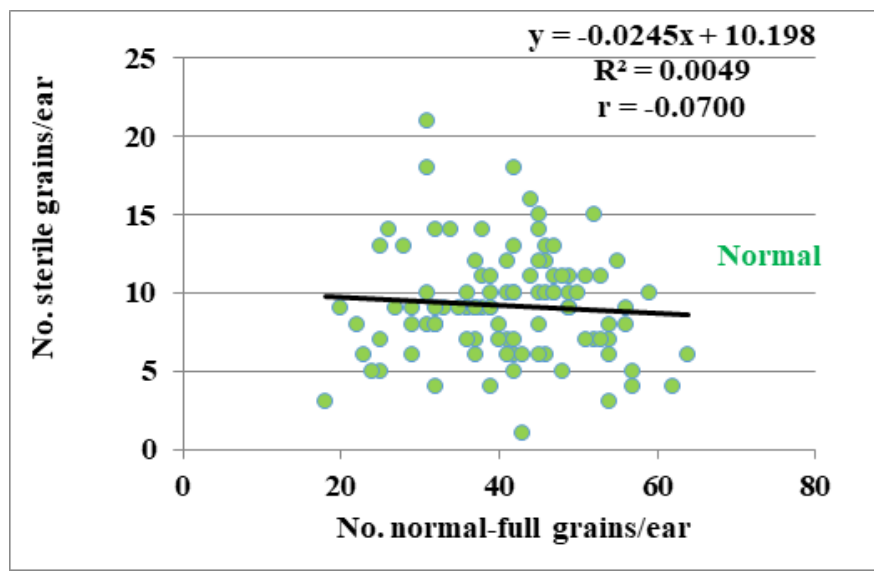

Figure 13. Correlation between no. of full grains/ear and no. of sterile grains/ear in normal barley

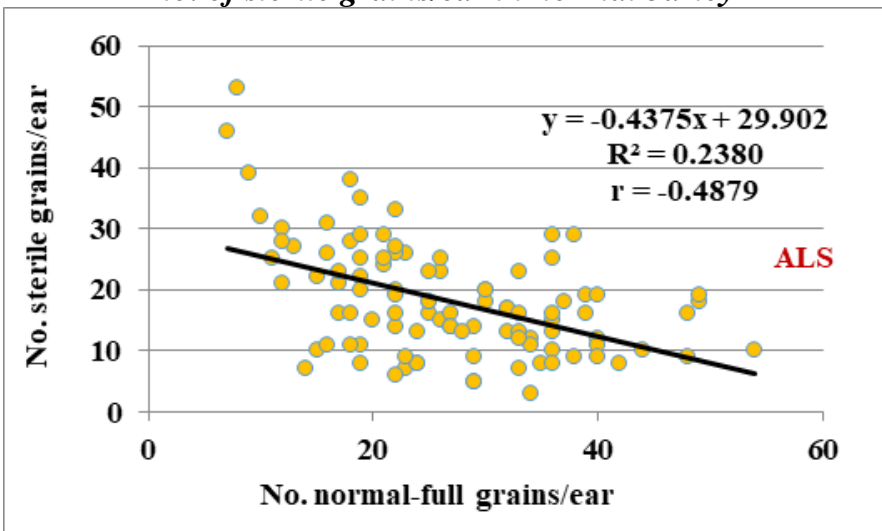

Figure 14. Correlations between no. of normal-full grains/ear and no. of sterile grains/ear in affected barley

Absolute weight of grains. Barley grain sprouts had the absolute lower weight due to a mass of one thousand grains shows, compared to the normal situation, a reduction from about $50 \mathrm{~g}$ to about 40 $\mathrm{g}$, for the ALS herbicide effect (Figure 15 and Figure 16).

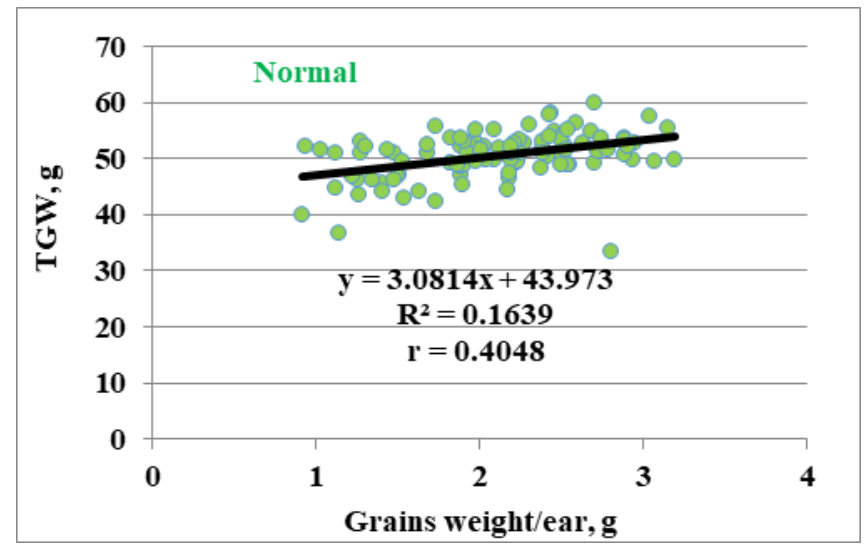

Figure 15. Correlation between grains weight/ear and thousand grains weight- TGW in normal barley 


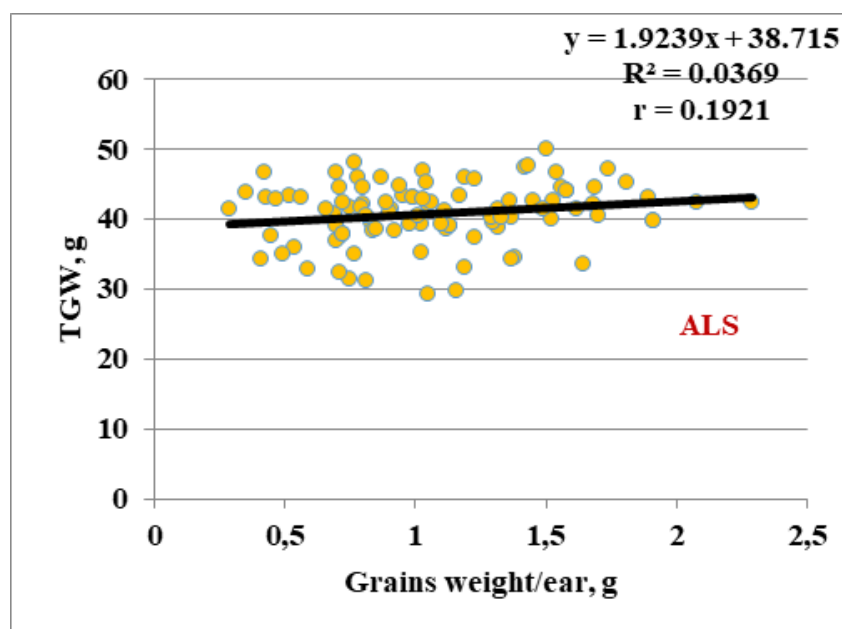

Figure 16. Correlations between grains weight/ear and thousand grains weight-TGW in affected barley

The connection between the two characters is positive in both cases, which demonstrates that, as long as grains of higher weight are formed, they will also have a larger mass. It is also worth noting the higher of barley spreading of affected barley values.

\section{CONCLUSIONS}

The weeds control from barley crop is an important economic measure. This is part of the integrated weed management-IWM. With the emergence of invasive weed species from the group of monocots: Apera, Avena, Bromus, Lolium, Vulpia, herbicide control becomes more and more difficult. For these species, treatment with classical products is no longer sufficient. If for wheat there are herbicides from the group of sulfonylurea (SU), which control the entire spectrum of species (dicots and monocots), the same products are not recommended for barley due to the low selectivity of the plants. In practice, the use of those products has been attempted at any risk due to the very high degree of infestation with monocot weeds. The damage they produce is particularly important. In this paper, barley crop was treated under recommended conditions: twinned, with recommended doses of the SU herbicide group having ALS activity.

The low selectivity of barley plants in ALS-type herbicides has led to a shortening of straw length and the entire productive ears spectrum: length, weight, number of grains. Thus, if at normal barley the ear measured an average of $6.7 \mathrm{~cm}$, the affected barley ears had $5.6 \mathrm{~cm}$, the difference due to the damage of the spike's peak. Under these conditions, the weight of the ear dropped from $2.43 \mathrm{~g}$ to only $1.31 \mathrm{~g}$. The number of grains in one ear was reduced from 41 to 27 by ALS treatment and the weight of the grains in one ear fell from $2.09 \mathrm{~g}$ to $0.98 \mathrm{~g}$.

An important category was the sterile spikelets (grains). Their presence on the ear confirmed a very important increase from 9.3/ear to normal barley at 18.2/ear to barley affected ALS. The correlation between the weight of the ear with this number of sterile spikelets has shown the lack of any link to normal barley and in barley with physiology affected. In the latter case, as the grains affected by the herbicide remain close to the normal ones, the sterile spikelets will be fewer. Between whole and sterile grains there was no relationship to normal barley, while barley affected, the relationship was negative. 
The correlation between the weight of the grains in a spike with a mass of one thousand grains had positive ratios in both cases, less approx. $10 \mathrm{~g}$ in the case of herbicide-affected barley. Due to these it is not recommended to use ALS herbicides in winter barley crop.

\section{REFERENCES}

Abeledo, G., Calderini, D., Slafer, G. (2002). Physiological changes associated with genetic improvement of grain yield in barley. Barley science recent advances from molecular biology to agronomy of yield and quality. Food Products Press, 361-385.

Brad, I., Ţerbea, M., Marcu, Z., Hurduc, N. (1972). Modificări ale spectrului izoperoxidazic la plantele de grâu, orz şi ovăz sub influenţa tratamentului cu giberelină. [Modifications of izoperoxidazic spectrum in wheat, barley and oat plants by treatment with gibbereline]. Studii de Cercetări în Biochimie, 17, 11-14.

Cattivelli, L., Ceccarelli, S., Romagosa I., Stanca, M. (2011). Abiotic Stresses in Barley- problems and solutions. Barley, Production, Improvement and Uses. Blackwell Publishing Ltd.

Coleman, J.O.D., Blakeka, L.F.F., Davies, T.G.E. (1997). Detoxidication of xenobiotics by plants: chemical modification and vacuolar compartimentation. Trends in Plant Science, 2, 144- 151.

Cuesta-Marcos, A., Casas, A., Hayes, P.M., Garcia, M.P., Lasa, J.M. (2009). Yield QTL affected by heading date in Mediterraneum grown barley. Plant Breeding, 128, 46-53.

Fox, P., Glen, K., Poulsen, D., Inkerman, D., Andy, H.R. (2006). Selectivity for increased barley grain size. Journal of Cereal Science, 43, 148-208.

Edwards, R. (1997). Glutathione transferases and herbicide metabolism and selectivity. Weed and Crop Resistance to Herbicide. Kluwer Academic Press, 109-115.

Jeźowski, S., Surwa, M., Adamski, T. (2001). Genetic control of morphological and physical characteristics determining resistance to lodging in barley (Hordeum vulgare L.). International Agrophysies, 15, 157-160.

Kjaer, B., Jenson, J., Giesse, H. (1995). Quantitative trait loci for heading date and straw characters in barley. Genome, 38, 1098-1104.

Mishra, B.N., Shivakumar, B.G. (2000). Barley, Techniques and Management of Field Crop Production. Agrobios, 478.

Tal, A., Romano, M.L., Stephenson, G.R., Schwan, A.L., Hall, J.C. (1993). Glutathione conjugation- a detoxification pathway for fenoxaprop- ethyl in barley, crabgrass, oat and wheat. Pesticide Biochemistry and Physiology, 46, 190-199.

Von Bothmer, R., Jacobsen, N., Badeu, C., Jorgensen, R.B., Linde-Laursen, I. (1995). An ecogeographical study of the genus Hordeum. International Plant Genetic Resources Institute, FAO Rome.

Zglimbea, G.R., Harms, H. (1997). Studies on the implication of ABA, total glutathione and glutathione reductase in plant drought resistance. Proceedings of International Symposium „Drought and Plant Production”, Serbia, 1, 431-437. 